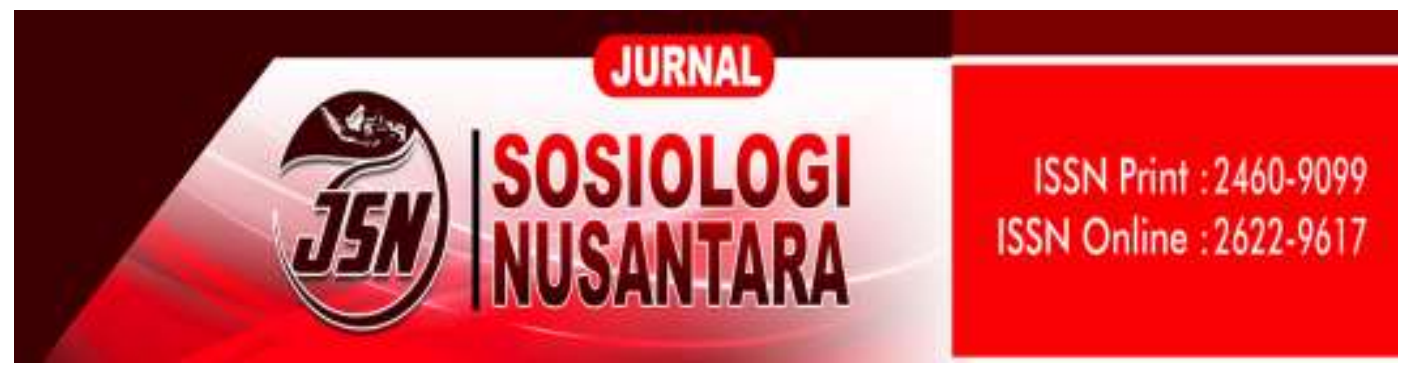

\title{
PENGASUHAN JARAK JAUH PADA ANAK PEREMPUAN \\ YANG DITINGGAL MERANTAU ORANG TUA TERHADAP PERILAKU SOSIAL ANAK
}

\section{LONG DISTANCE PARENTING IN DAUGHTERS WHO WERE LEFT OVERSEAS BY PARENTS TOWARDS CHILDREN'S BEHAVIOR}

\author{
Retno Ayu Feriwati ${ }^{1}$, Yuhastina ${ }^{2}$ \\ retnoayu.ra14@gmail.com
}

${ }^{1,2}$ Fakultas Keguruan dan Ilmu Pendidikan, Universitas Sebelas Maret Surakarta

\begin{abstract}
Abstrak
Di dalam sebuah keluarga, orang tua mempunyai kewajiban untuk mengasuh serta mendidik anak-anaknya agar dapat menjadi manusia yang berdaya guna. Pengasuhan orang tua sangat penting dalam keluarga, melalui proses internalisasi yang dilakukan oleh orang tua kepada anak, diharapkan anak akan tumbuh menjadi pribadi yang bisa diterima masyarakat. Adanya fenomena migrasi yang hampir terjadi di setiap daerah, memunculkan berbagai permasalahan, salah satunya berkaitan dengan dampak anak yang ditinggal merantau oleh orang tua. Orang tua di Dusun Bedug yang pergi merantau ke luar daerah biasanya menitipkan anak mereka kepada nenek maupun kerabat dekat lainnya. Sehingga orang tua seringkali tidak terlibat secara penuh dalam mendidik dan mengontrol sang anak karena terpisahkan oleh jarak. Penelitian ini bertujuan untuk mengetahui penerapan pengasuhan jarak jauh yang dilakukan orang tua kepada anak perempuan yang ditinggal merantau serta dampak pengasuhan jarak jauh tersebut terhadap perilaku sosial anak perempuan yang ditinggal merantau. Penelitian ini merupakan penelitian kualitatif dengan menggunakan pendekatan studi kasus. Berdasarkan hasil penelitian, orang tua yang pergi merantau di Dusun Bedug melakukan pengasuhan secara tidak langsung yakni dengan memanfaatkan teknologi komunikasi seperti dengan bertelepon maupun video call. Tidak adanya kehadiran orang tua secara langsung dalam mengasuh dan mendidik anak membuat fungsi Integration (Integrasi) tidak berjalan sesuai semestinya atau rusak. Akibatnya, hal ini membuat sang anak bertindak sesuka hati karena
\end{abstract}


kurangnya pengawasan serta kontrol dari orang tua. Ini menunjukkan bahwa pengasuhan jarak jauh yang diterapkan oleh orang tua yang merantau berdampak pada perilaku sosial anak perempuan yang ditinggal merantau.

Kata Kunci : Jarak Jauh, Merantau, Pengasuhan, Perilaku Sosial

\section{Abstract}

In a family, parents must nurture and educate their children to become powerful human beings. Parents' parenting method is very important in the family, through the internalization process made by parents to children, the child is expected to grow into a person who can be accepted by society. The Migration phenomena that almost occur in every region are making many problems rising, one of them is related to the impact of children who were left overseas by parents. The parents in Bedug village who went outside the area usually entrust their children to the grandmothers and other close relatives. So that parents often do not fully engage in educating and controlling the child because they are separated by distance. This research aims to determine the application of long-distance parenting patterns that parents do to daughters who were left overseas and the impact of these long-distance parenting patterns on the social behavior of these daughters who were left overseas by their parents. This study is a qualitative study using a case study approach. Based on the results of the study, parents who go overseas in the Bedug village will do a pattern of parenting indirectly by utilizing communication technology such as phone and video calls. The absence of a direct parental presence in parenting and educating the child makes the Integration function not run as intended or corrupted. Consequently, this makes the child act at their own pace due to a lack of supervision and parental control. From this study, it can be concluded that the long-distance parenting pattern applied by the overseas parents has an impact on the social behavior of the daughters who are left overseas.

Keywords : Long-Distance, Overseas, Parenting, Social Behavior

\section{PENDAHULUAN}

Keluarga merupakan salah satu unsur terpenting di dalam proses perkembangan dan pembentukan karakter anak. Reiss (dalam Lestari, 2016), mengatakan bahwa keluarga adalah kelompok kecil yang terstruktur dalam pertalian keluarga yang mana memiliki fungsi utama yakni sosialisasi pemeliharaan nilai maupun norma terhadap generasi baru. Sedangkan Weigert dan Thomas (dalam Lestari, 2016), mendefinisikan keluarga didasarkan pada pentingnya suatu budaya ditransmisikan pada generasi berikutnya dalam rangka menjadikan anak-anak tumbuh sebagai manusia yang dapat menjalankan fungsinya. Suatu budaya yang perlu ditransmisikan mereka sebut dengan pola- 
pola nilai yang bersifat simbolik (symbolic pattern value). Dari keluargalah seorang anak akan mendapatkan proses sosialisasi yang pertama, utamanya dari orang tua. Dalam proses sosialisasi tersebut anak akan ditanamkan nilai-nilai serta norma yang sesuai dan berlaku di masyarakat.

Di dalam sebuah keluarga, orang tua mempunyai kewajiban untuk mengasuh serta mendidik anak-anaknya agar dapat menjadi manusia yang berdaya guna. Pengasuhan orang tua sangat penting dalam keluarga, hal itu berlangsung melalui proses internalisasi nilai-nilai kebudayaan dari orang tua kepada anak. Melalui proses internalisasi yang dilakukan oleh orang tua kepada anak, diharapkan anak akan tumbuh menjadi pribadi yang bisa diterima di masyarakat. Jane B. Brook (2013), dalam bukunya yang berjudul The Process of Parenting, mendefinisikan pengasuhan sebagai proses interaksi dan tindakan antara orang tua dengan anak. Masyarakat adalah kekuatan dinamis ketiga dalam proses tersebut. Anak, orang tua, serta masyarakat seluruhnya mempengaruhi proses pengasuhan.

Adanya fenomena migrasi yang hampir terjadi di setiap daerah, memunculkan berbagai permasalahan salah satunya berkaitan dengan dampak anak yang ditinggal merantau oleh orang tuanya. Berdasarkan berita yang dilansir dari bbc.com (2017), menurut Kepala Sekolah SMAN Wanasaba, Kabupaten Lombok Timur, di sekolah tersebut hampir 52\% dari total siswa sebanyak 470 adalah anak-anak TKI. Selain motivasi belajar di sekolah yang berkurang, dampak lain yang terjadi pada anak-anak buruh migran juga dilihat dari segi psikologis. Anak-anak yang ditinggal merantau oleh orang tuanya ini cenderung memiliki rasa tidak percaya diri ketika di sekolah. Hal ini tentu saja akan mengganggu prestasi anak selama menjalani pendidikan. Selain dampak motivasi belajar yang rendah, dampak lain yang sangat sering terjadi akibat tidak adanya kehadiran sosok orang tua dalam mengasuh serta mendidik anak ialah perilaku sosial anak yang seringkali menyimpang dari nilai-nilai dan norma yang berlaku di masyarakat. Permasalahan ini jamak terjadi karena anak merasa tidak diberi perhatian maupun kasih sayang dari orang tuanya, serta kurangnya kontrol sosial yang dilakukan oleh orang tua kepada anak-anak mereka yang ditinggal merantau. 
Penelitian Sukamdi dkk (2011), yang berjudul, "Dampak Migrasi Internasional Terhadap Keluarga dan Anak yang ditinggalkan” yang dilakukan di beberapa daerah atau kota di Jawa Barat serta Jawa Timur dimana penelitian ini bagian dari comparative studies, "Children Health and Migrant Parents in Southeast Asia (CHAMPSEA)" yang dilakukan di empat negara yakni Indonesia, Thailand, Vietnam, serta Filipina. Hasil penelitian menunjukkan bahwa terdapat perbedaan antara anak yang ditinggal merantau dengan anak yang tidak ditinggal merantau oleh orang tuanya. Anak-anak yang ditinggal merantau teridentifikasi mempunyai kondisi psikologis yang kurang baik dibandingkan dengan kondisi psikologis anak yang tidak ditinggal merantau. Permasalahan psikologis yang dialami oleh mereka yakni seperti mudah marah, bermasalah dengan teman sebaya, serta hiperaktif. Secara psikologis, anak-anak yang tinggal bersama kedua orang tuanya menyatakan lebih bahagia jika dibandingkan dengan anak-anak yang ditinggal merantau orang tua.

Berdasarkan Badan Pusat Statistik Kabupaten Ngawi, jumlah angkatan kerja di Kabupaten Ngawi pada tahun 2013 sebanyak 477.534 jiwa. Sedangkan lapangan kerja yang tersedia di Kabupaten Ngawi pada 2013 hanya 3.735. Sedikitnya lapangan kerja di Kabupaten Ngawi mendorong para warganya untuk berbondong-bondong mencari pekerjaan ke luar daerah maupun luar negeri. Menurut data dari Dinas Perdagangan Perindustrian dan Tenaga Kerja (DPPTK) Kabupaten Ngawi, pada tahun 2018 sendiri terjadi peningkatan jumlah migran yang bekerja ke luar negeri yakni sebanyak 1.275 warga.

Dari hasil penelitian UNICEF (dalam Danastri, 2013), dapat diketahui bahwa anak-anak Moldova yang ditinggal orang tuanya pergi merantau memiliki dampak psikologis dimana mereka kurang mampu dalam mengatasi kesulitankesulitan pada kehidupan dewasanya. Anak-anak yang ditinggal merantau tersebut umumnya mengalami kesulitan dalam pengambilan keputusan, kurangnya rasa percaya diri, serta sulit dalam mengendalikan emosinya. Selain itu dalam bidang pendidikan, anak-anak tersebut juga mengalami kemunduran prestasi akademik hingga hilangnya minat sekolah. 
Berbagai permasalahan sosial maupun psikologis pada anak yang ditinggal merantau orang tua juga terjadi di Dusun Bedug yang mana tidak sedikit warganya yang pergi merantau ke luar pulau. Dusun Bedug merupakan salah satu dusun yang terdapat di Desa Sriwedari, Kecamatan Karanganyar, Kabupaten Ngawi, Jawa Timur. Berdasarkan data BPS Kabupaten Ngawi, jumlah penduduk Desa Sriwedari pada tahun 2017 yakni sebanyak 2.870 jiwa, dimana 20\% masyarakatnya meratau ke luar daerah atau ke luar pulau. Dengan demikian terdapat 574 jiwa warga Desa Sriwedari yang merantau. Di Dusun Bedug sendiri, jumlah warga yang merantau yakni sebesar 7\%. Orang tua di Dusun Bedug yang pergi merantau ke luar daerah biasanya menitipkan anak-anak mereka kepada nenek, maupun kerabat dekat yang lainnya. Sehingga orang tua seringkali tidak terlibat secara penuh dalam mendidik dan mengontrol anak-anaknya karena terpisahkan oleh jarak dan kesibukan dalam mencari nafkah. Berdasarkan latar belakang yang telah dipaparkan diatas, penelitian ini bertujuan untuk mengetahui penerapan pengasuhan jarak jauh yang dilakukan orang tua kepada anak perempuan yang ditinggal merantau serta bagaimana dampak pengasuhan jarak jauh tersebut terhadap perilaku sosial anak perempuan yang ditinggal merantau. Di dalam penelitian ini teori yang digunakan ialah teori Fungsional Struktural oleh Talcott Parsons.

\section{METODE PENELITIAN}

Penelitian ini merupakan penelitian kualitatif dengan pendekatan studi kasus. Creswell (dalam Gunawan, 2015) mengemukakan bahwa penelitian studi kasus ialah penelitian terhadap suatu objek tertentu yang disebut sebagai sebuah kasus, yang mana pada prosesnya dilakukan secara detail menggunakan berbagai macam sumber data. Penelitian ini dilaksanakan di Dusun Bedug, Desa Sriwedari, Kecamatan Karanganyar, Kabupaten Ngawi, Jawa Timur. Sumber data pada penelitian ini terdiri dari dua data yakni data primer yang diperoleh secara langsung dari informan serta data sekunder yang merupakan data pendukung dari data primer dan sebagai penguat informasi. Metode pengambilan sampel pada penelitian ini ialah purposive sampling, yang digunakan untuk memilih informan 
yang dianggap paling mengerti dan memahami permasalahan yang tengah diteliti. Dalam penelitian ini peneliti memfokuskan pada 3 (tiga) anak perempuan yang ditinggal merantau orang tua dimana tiap-tiap informan tersebut merupakan narasumber utama dari pengasuhan jarak jauh anak perempuan yang ditinggal merantau orang tua. Kasus-kasus terkait pengasuhan jarak jauh anak perempuan yang ditinggal merantau orang tua tersebut yakni, kasus pulang malam, mengkonsumsi minum-minuman keras, serta mengkonsumsi pil ekstasi. Dari masing-masing 3 (tiga) informan perempuan tersebut peneliti juga mewawancarai orang tua yang merantau, pengasuh pengganti atau orang tua tunggal, teman anak perempuan yang ditinggal merantau, tetangga, serta wali kelas anak perempuan yang ditinggal merantau tersebut.

Para informan yang telah disebutkan di atas dipilih oleh peneliti terkait nilai informatif yang dimiliki mengenai pengasuhan jarak jauh pada anak perempuan yang ditinggal merantau. Anak perempuan dipilih sebagai subjek utama pada penelitian ini karena perempuan lebih sering mengalami seksisme dari masyarakat utamanya pada masyarakat tradisional. Dalam hal ini, masyarakat seringkali melakukan diskriminasi dalam merespon kenakalan maupun perilaku menyimpang antara anak laki-laki dengan perempuan yang ditinggal merantau. Oleh karena itu, penelitian ini dilakukan untuk melihat dan mengetahui secara lebih jelas dampak anak yang ditinggal merantau orang tua baik secara sosial maupun psikologis dari sudut seorang anak perempuan.

Hasil data dari penelitian ini dikumpulkan dengan teknik wawancara mendalam serta observasi dengan melihat langsung aktivitas yang dilakukan oleh anak perempuan yang ditinggal merantau orang tua, orang tua tunggal, ataupun pengasuh pengganti orang tua. Selanjutnya data yang telah terkumpul dianalisis menggunakan teknik triangulasi sumber untuk menguji keabsahan data. Teknik triangulasi sumber berguna untuk memperoleh data yang valid dengan membandingkan hasil wawancara yang sudah diperoleh pada sumber yang berbeda. 


\section{PEMBAHASAN}

Pengasuhan anak merupakan serangkaian interaksi dan tindakan yang dilakukan oleh orang tua kepada anak dalam rangka mendukung tumbuh kembang anak. Dalam proses pengasuhan anak, hubungan tidak hanya berjalan satu arah akan tetapi terjadi pula proses interaksi antara orang tua dengan anak yang dipengaruhi oleh nilai-nilai budaya serta norma yang dijunjung dimasyarakat. Dari proses pengasuhan tersebut anak dapat belajar mana yang pantas dan tidak pantas, anak memahami perannya, serta mentransmisikan nilai-nilai budaya dari orang tua kepada anak. Pengasuhan yang diterapkan oleh orang tua nantinya akan berpengaruh terhadap tumbuh kembang dan perilaku anak dalam kehidupan sehari-hari. Seringkali perilaku anak sehari-hari ketika melakukan interaksi sosial akan menjadi penilaian apakah orang tua telah menerapkan pola pengasuhan yang tepat ataukah belum. Hal ini dikarenakan dari proses sosialisasi anak dengan masyarakat akan terlihat apakah anak tumbuh sesuai dengan nilai-nilai yang dipegang oleh masyarakat atau justru menyimpang dari nilai dan norma yang berlaku di masyarakat.

Penerapan pengasuhan jarak jauh merupakan suatu pilihan yang mau atau tidak harus dilakukan oleh orang tua yang memilih untuk mencari penghasilan di tanah rantau. Meskipun jauh dari anak, orang tua yang merantau tetap berusaha untuk memiliki bonding dengan anak. Melalui panggilan telepon maupun video call orang tua senantiasa berusaha hadir untuk anak. Dengan melakukan komunikasi setiap hari orang tua berharap masih bisa menjalankan perannya dalam mendidik dan membimbing anak meski tidak secara langsung. Selain pengasuh pengganti, orang tua juga meminta informasi terkait perilaku anaknya dengan bertanya kepada para tetangga.

Meskipun orang tua sudah berusaha semaksimal mungkin dalam mendidik anaknya dari jauh akan tetapi dalam kerberjalanannya proses internalisasi yang dilakukan oleh orang tua secara virtual masih tidak bisa menggantikan penerapan pengasuhan secara langsung. Anak yang ditinggal merantau tetap merasakan rasa kasih sayang yang kurang dibanding teman-temannya yang tidak ditinggal merantau. Kurangnya perhatian dari orang tua membuat mereka tidak jarang 
mencari atensi dari lingkungan luar seperti melakukan perilaku-perilaku menyimpang.

Ketiadaan sosok orang tua yang hadir utuh secara fisik membuat anakanak yang ditinggal merantau merasa bebas untuk melakukan segala sesuatu sesuai keinginan tanpa takut diketahui oleh orang tua bahkan pengasuh pengganti. Anak-anak yang ditinggal merantau sangat cerdik memainkan peran yang mana hal ini membuat orang tua tidak curiga terhadap perilaku sang anak ketika ditinggal merantau. Saat orang tua berada dirumah anak akan menjadi lebih penurut dan hampir tidak pernah keluar rumah karena takut dengan orang tua. Akan tetapi ketika orang tua sedang berada di perantauan sang anak akan kembali menjadi pribadi yang berperilaku menyimpang. Hal ini menunjukkan bahwa intensitas komunikasi tidak berpengaruh dalam mengawasi dan mengontrol segala tindak tanduk anak sehari-hari.

Perilaku-perilaku menyimpang yang dilakukan oleh anak yang ditinggal merantau sudah menjadi rahasia umum khususnya di Dusun Bedug dimana banyak warganya yang memilih untuk merantau ke luar daerah bahkan pulau untuk mencari kehidupan yang lebih layak dan mendapatkan kesejahteraan ekonomi. Dalam penelitian ini, peneliti melakukan penelitian pada remaja perempuan dengan tiga kasus yang berbeda yakni pulang malam, minumminuman keras, dan mengkonsumsi pil ekstasi. Berikut merupakan data informan anak perempuan yang ditinggal merantau :

Tabel.1 Informan anak perempuan yang ditinggal merantau orang tua

\begin{tabular}{cccc}
\hline Informan & Usia & Status & Kasus \\
\hline HS & 18 & Pelajar & Pulang Malam \\
\hline ND & 18 & Pelajar & Mengkonsumsi \\
& & & Minuman Keras \\
\hline AM & 17 & Pelajar & Mengkonsumsi Pil \\
& & & Ekstasi
\end{tabular}

Sumber : Data Peneliti 
Berdasarkan hasil wawancara dan observasi tidak adanya sosok orang tua yang hadir secara langsung begitu pula peran pengasuh pengganti yang tidak berfungsi dengan baik karena terbentur oleh usia yang sudah sangat tua menjadi penyebab mereka untuk melakukan perilaku-perilaku yang menyimpang. Selain itu hal lain yang menjadi faktor pendorong yakni karena lingkungan pergaulan. Orang tua yang tidak bisa memantau dan mengontrol langsung membuat sang anak perempuan jatuh pada lingkungan pergaulan yang salah. Rata-rata anak yang ditinggal merantau tidak lepas dari pulang malam bahkan pagi. Hampir setiap malam mereka keluar untuk pergi entah sekedar main, nongkrong, berpacaran maupun kegiatan lainnya. Perilaku pulang malam ini sangat jelas terlihat oleh para tetangga terlebih suasana dusun yang sepi membuat tetangga sangat mudah mengetahui pergerakan satu sama lain. Selain itu acap kali tetangga juga akan mengintip jika ada anak perempuan yang ditinggal merantau pulang pagi. Jika sudah begitu sang anak tersebut pun akan menjadi buah bibir oleh tetangga sekitar. Tidak jarang para tetangga akan melaporkan kejadian ini kepada orang tua dari si anak melalui sambungan telepon bahwa sang anak pulang larut. Akan tetapi, karena sang anak memberikan penjelasan-penjelasan yang meyakinkan bahwa mereka pulang malam karena ada kepentingan satu dan lain sebagainya seperti misalnya berlatih di suatu perguruan bela diri, ini membuat orang tua tidak percaya dengan apa yang dilaporkan oleh tetangga dan terkesan denial.

Selain pulang malam, anak-anak perempuan ini juga melakukan perilaku menyimpang lain seperti minum-minuman keras dan mengkonsumsi pil ekstasi. Tidak seperti perilaku pulang malam yang bisa diketahui oleh tetangga, perilaku menyimpang tersebut di atas tidak bisa diidentifikasi oleh para tetangga karena para anak-anak tersebut melakukannya di luar desa. Mereka yang melakukan aktivitas tersebut sengaja mencari aman dengan melakukan penyimpangan di luar desa agar tidak tertangkap basah oleh tetangga maupun teman di sekitar rumah yang kemudian informasi tersebut bisa terdengar sampai ke telinga orang tua mereka masing-masing.

Dari hasil penelitian di atas dapat diambil kesimpulan bahwa pengasuhan jarak jauh yang diterapkan oleh orang tua berdampak pada perilaku sosial anak 
perempuan yang ditinggal merantau. Penelitian ini didukung dengan adanya teori yang digunakan yaitu teori Fungsional Struktural dari Talcott Parsons. Asumsi dasar dari teori fungsional struktural ini sendiri ialah dimana setiap struktur mempunyai fungsi dan perannya masing-masing. Sehingga apabila ada tatanan atau struktur yang tidak fungsional maka struktur tidak berjalan sesuai semestinya atau rusak. Berangkat dari hal tersebut, Parsons percaya bahwa ada empat imperatif fungsional yang perlu bagi semua sistem yang dikenal dengan skema AGIL, yakni A (Adaptation), G (Goal Attainment), I (Integration), dan L (Latency). Agar dapat bertahan, suatu sistem harus melaksanakan keempat fungsi tersebut.

Keberadaan orang tua secara langsung dan nyata yang berperan sebagai Integration (Integrasi) sangat dibutuhkan dalam mengatur apa saja cara dan langkah yang tepat dalam mengasuh dan mendidik anak sehingga diharapkan akan terciptanya stabilitas keluarga. Berdasarkan hasil penelitian, orang tua yang pergi merantau di Dusun Bedug akan melakukan pola pengasuhan secara tidak langsung yakni dengan memanfaatkan teknologi komunikasi seperti dengan bertelepon maupun video call. Tidak adanya kehadiran orang tua secara langsung dalam mengasuh dan mendidik anak membuat fungsi Integration (Integrasi) tidak berjalan sesuai semestinya atau rusak. Akibatnya, hal ini membuat sang anak bertindak sesuka hati karena kurangnya pengawasan serta kontrol dari orang tua. Konsekuensi yang harus diterima dari ketidakberjalanan fungsi tersebut ialah anak-anak perempuan yang ditinggal merantau oleh orang tua menjadi melakukan berbagai perilaku menyimpang seperti pulang malam, mengkonsumi minumminuman keras serta mengkonsumsi pil ekstasi.

Berdasarkan hasil penelitian yang dikaitkan dengan skema AGIL, pengasuhan yang diterapkan oleh orang tua yang merantau mengalami Adaptation (Adaptasi) karena jarak yang berjauhan. Rata-rata warga Dusun Bedug, Desa Sriwedari, Kabupaten Ngawi sendiri pergi merantau ke Pulau Kalimantan, sebagian besar dari mereka bekerja sebagai penjual cilok, penjual es potong keliling, penjual jamu keliling, maupun penjual pakaian. Jarak yang jauh membuat mereka sebagai orang tua mau tidak mau harus cerdas dalam memanfaatkan 
teknologi sebagai media komunikasi. Para orang tua biasanya menggunakan aplikasi Whatsapp untuk melakukan panggilan maupun video call dengan sang anak sebagai upaya untuk mengontrol segala perilaku anak sehari-hari. Hampir setiap hari orang tua yang merantau menghubungi sang anak untuk menanyakan segala aktivitas anak pada hari itu. Dengan adanya komunikasi yang terjalin setiap harinya orang tua berharap hal tersebut dapat membangun bonding dengan sang anak meskipun orang tua tidak bisa menemani tumbuh kembang sang anak secara langsung.

Selain itu, orang tua juga berharap meskipun secara lahiriah tidak bisa berada di sisi sang anak, mereka tetap ingin anak mereka tahu bahwa mereka di kasihi dan di sayangi. Goal Attainment (Pencapaian tujuan), dalam skema AGIL pencapaian tujuan juga sudah tercermin dalam pemaparan proses adaptasi. Dengan intensitas komunikasi yang dilakukan oleh orang tua kepada anak, orang tua sebagai pihak yang merasa bertanggung jawab dalam mendidik dan membimbing proses tumbuh kembang anak berharap bisa mendidik anak mereka menjadi pribadi yang taat nilai dan norma. Sehingga dengan demikian orang tua berharap nantinya anak bisa diterima oleh masyarakat. Integration (Integrasi), integrasi dalam skema berperan dalam penerapan pengasuhan. Integrasi merupakan suatu sistem yang mengatur antarhubungan menjadi sebuah komponen. Orang tua merupakan pihak yang berkewajiban dalam mengatur proses internalisasi yang akan diberikan kepada anak-anak mereka. Tanpa adanya peran serta orang tua secara langsung dalam mengatur akan membuat anak mengalami disonansi kognitif. Dalam penerapan pengasuhan adanya peran serta orang tua secara langsung sangat berpengaruh terhadap output yang dihasilkan. Kehadiran orang tua secara langsung dalam mendidik dan mengarahkan anak sangat berpengaruh terhadap perilaku dan psikis anak serta keputusan anak dalam bertindak tidak terkecuali berkaitan dengan pemilihan lingkungan pergaulan. Sosok orang tua yang merupakan agen sosialisasi pertama bagi anak secara otomatis akan membuat orang tua mengatur bagaimana cara dan langkah-langkah yang tepat agar anak bisa tumbuh menjadi manusia yang bisa membedakan baik 
dan buruk, benar dan salah sehingga dengan demikian diharapkan akan terjadinya stabilitas dalam keluarga.

Skema AGIL yang terkhir yakni, Latency (Pemeliharaan pola). Pemeliharaan dimana suatu sistem harus memelihara dan memperbarui motivasi individu maupun pola-pola budaya yang menciptakan dan menopang motivasi tersebut. Dalam pengasuhan jarak jauh, orang tua senantiasa memberikan nasihat maupun motivasi kepada anak-anak mereka agar mereka dapat bertindak dengan mematuhi nilai-nilai serta norma yang dianut dan diyakini oleh masyarakat sekitar. Ketika memberikan motivasi tersebut juga terlihat pemeliharaan pola budaya dimana orang tua memberi tahu bagaimana seyogyanya menjadi perempuan yang mengenal adat ketika berperilaku atau bertindak.

Dalam penelitian ini peran orang tua sebagai pengintegrasi yang tidak dapat mengasuh, mendidik, serta membimbing anak-anak mereka secara langsung menjadikan anak-anak mereka berperilaku semaunya yang mana hal itu tidak sesuai dengan nilai-nilai dan norma yang ada ditengah-tengah masyarakat. Anakanak yang ditinggal merantau merasa dirinya bebas melakukan apapun tanpa takut diketahui oleh orang tua mereka karena sejatinya orang tua tidak bisa benar-benar tahu apa yang dilakukan anak-anaknya ketika diluar rumah. Bahkan pengasuh pengganti yang notabene hidup berdampingan saja tidak mengetahui dengan pasti apa yang dilakukan sang cucu ketika keluar rumah. Peran pengasuh pengganti atau nenek sendiri bisa dibilang kurang berfungsi dalam mengontrol perilaku sang cucu selama ini. Pada akhirnya penerapan pengasuhan jarak jauh yang mana tidak adanya peran orang tua secara langsung inilah yang berdampak pada perilaku menyimpang anak perempuan yang ditinggal merantau khususnya di Dusun Bedug, Desa Sriwedari, Kecamatan Karanganyar, Kabupaten Ngawi.

\section{KESIMPULAN}

Sedikitnya ketersediaan lapangan pekerjaan dan mata pencaharian di Dusun Bedug membuat para warganya berduyun-duyun memutuskan untuk pergi merantau ke luar daerah bahkan luar pulau. Para orang tua yang merantau terpaksa harus meninggalkan anak-anaknya demi memperoleh kesejahteraan ekonomi. 
Agar tetap dapat terjalin bonding dengan anak, orang tua sebagai pihak yang bertanggung jawab dalam mengasuh, mendidik, serta membimbing anak senantiasa semaksimal mungkin untuk melakukan komunikasi dengan anak-anak mereka yang ditinggal merantau. Setiap harinya orang tua selalu menghubungi sang anak melalui telepon maupun video call untuk mengetahui kegiatan yang sedang dan akan dilakukan oleh sang anak pada hari itu.

Meskipun demikian, realitanya intensitas komunikasi yang dilakukan oleh orang tua tidak bisa menggantikan pengasuhan orang tua yang dilakukan secara langsung. Tidak adanya kehadiran orang tua secara langsung dalam mengatur apa saja cara dan langkah yang tepat dalam mengasuh dan mendidik anak membuat sang anak melakukan perilaku-perilaku menyimpang seperti pulang malam, minum-minuman keras, dan mengkonsumsi pil ekstasi. Oleh karenanya, diperlukan partisipasi semua pihak terutama keluarga dan kerabat di kampung halaman untuk membantu mengontrol perilaku anak yang ditinggal merantau. Baik dengan memberikan edukasi, nasihat, maupun pengertian mengenai hal-hal apa saja yang baik dan salah, sehingga anak akan mengetahui nilai-nilai dan norma apa saja yang berlaku di masyarakat. Selain itu, ada baiknya anak tidak ditinggal merantau dengan sang nenek semata akan tetapi diperlukan pula kehadiran orang tua tunggal. Hal ini dikarenakan anak yang hanya ditinggal dan diasuh oleh nenek seringkali mengabaikan dan menyepelekan kehadiran sang nenek.

\section{DAFTAR PUSTAKA}

Bonasir, Rohmatin. 2017. "Bagaimana Nasib Anak-Anak Yang Ditinggalkan Ibu Mereka Menjadi TKI Dan Diasuh Oleh Kerabat?” BBC Indonesia. Retrieved November 19, 2019 (https://www.bbc.com/indonesia/indonesia-39138971).

Brooks, Jane. 2013. The Process of Parenting. 9th ed. edited by A. Lonn. New York: Mc Graw Hill.

Danastri, Prihantini. 2013. "Problem Psikososial Pada Remaja Yang Orang Tuanya Merantau." Universitas Muhammadiyah Surakarta. 
Fakhrina, Intan. 2017. "Merantau Dan Pulang Basamo: Studi Reinterpretasi Pola Migrasi Pada Masyarakat Minangkabau Di Bandar Lampung.” Universitas Lampung.

Faradita, Sania. 2013. "Perbedaan Psychological Well-Being Pada Dewasa Muda Pasangan Long Distance Relationship Dengan Pasangan Non Long Distance Relationship.” Universitas Bina Nusantara, Jakarta.

Gunawan, Imam. 2015. Metode Penelitian Kualitatif. 3rd ed. edited by Suryani. Jakarta: Bumi Aksara.

James, Allison dan Adrian James. 2012. Key Concepts in Childhood Studies. 2nd ed. edited by C. Rojek. London: SAGE Publications.

Lestari, Sri. 2016. Psikologi Keluarga; Penanaman Nilai Dan Penanganan Konflik Dalam Keluarga. 4th ed. Jakarta: KENCANA.

Ritzer, George. 2012. Teori Sosiologi. 8th ed. Yogyakarta: PUSTAKA PELAJAR.

Selin, Helaine, ed. 2014. Parenting Across Cultures. New York: SPRINGER.

Yeoh, Brenda, Elsepth Graham, Sukamdi, Anna Marie Wattie, Dewi Haryani Susilastuti, Wini Tatiari, Agus Joko Pitoyo, Sri Purwatiningsih, and Edy Kiswanto. 2011. "Dampak Migrasi Internasional Terhadap Keluarga Dan Anak Yang Ditinggalkan: Studi Kasus Indonesia." Link dapat diakses : http://smeru.or.id/sites/default/files/events/05_the_impacts_of_parental_migr ation_on_health_and_well-being_-_dr_sukamdi_0.pdf 